\title{
Пі.лоніда.льна хвороба у дітей. Чи усі питання патогенезу вирішені?
}

\begin{abstract}
Мета роботи: визначити можливі анатомічні чинники патогенезу пілонідальної хвороби в дітей.
Матеріали і методи. Проведено аналіз результатів клініко-морфологічних обстежень 37 дітей 3 діагнозом “пілонідальна хвороба”, пролікованих з 2010 по 2017 рік на базі Вінницької обласної дитячої клінічної лікарні. Середній вік пацієнтів складав $(16,4 \pm 0,4)$ року; хлопчиків було 26 та 11 дівчаток. Для порівняння морфологічної будови пілонідальної кісти із дорослими пацієнтами використовували 17 зразків видалених раніше тканин, які були на обліку в архіві обласного патанатомічного бюро. Результати досліджень та їх обговорення. У 75 \% препаратів у дорослих спостерігали відсутність епітеліальної вистилки, що є результатом тривалого рецидивного перебігу пілонідальної хвороби. Останнє сприяє швидкій хронізації запального процесу та виникненню гіалінозу судинних стінок у стінці кісти. Також майже в 94 \% випадків у дорослих стінки пілонідальної кісти складались із грубоволокнистої сполучної тканини з вираженою лімфогістіоцитарною інфільтрацією, а у просвіті їх визначались деривати шкіри. Схожі морфологічні ознаки були виявлені лише у 30 \% дітей, а у порожнині кісти були виявлені волосяні стрижні з ознаками часткового лізису, які були пов'язані із неатрофованими волосяними цибулинами, що чітко не свідчило на користь їх екзогенного трансдермального проникнення. У 41,66 \% дітей при гістологічному обстеженні навколо куприкового ходу визначалась незріла мезенхімоподібна тканина. За рахунок щільної фіксації шкіри міжсідничної складки із оточуючими тканинами при рухах виникає її зміщення й розтягнення пор, в яких накопичуються секрети шкіри та її деривати, які ще більше її розтягують й при виникненні запалення сприяють ії самовільному розкриттю. Тому пілонідальна хвороба - це поліетіологічне захворювання, однією із причин розвитку якої є підвищена локальна пітливість тіла, що зумовлює ряд додаткових провокаційних факторів утворення гострого абсцесу міжсідничної ділянки, підтримання хронічного запалення та рецидивного перебігу захворювання.
\end{abstract}

Ключові слова: пілонідальна хвороба; діти; дитяча хірургія.

Постановка проблеми і аналіз останніх досліджень та публікацій. У фаховій медичній літературі під терміном “пілонідальна хвороба” (ПХ) позначають комплекс патологічних проявів, які формуються під впливом несприятливих анатомо-фізіологічних чинників та зовнішніх факторів, кінцевим морфологічним субстратом якої $\epsilon$ формування пілонідальної кісти крижово-куприкової ділянки, ключову роль в етіопатогенезі якого відіграє запалення придатків шкіри на дні міжсідничної складки та в просвіті первинних норицевих ходів, частіше всього у вигляді гострого гнійного фолікуліту [1].

Відповідно до класифікації американської асоціації колоректальних хірургів, ПХ - це хронічна шкірна інфекція, яка розташовується на дні міжсідничної складки (в проекції куприка). Дане визначення, на наш погляд, не повністю пояснює суть патології. Більш широким та точним $\epsilon$ наступне: ПХ - це гострий пілонідальний абсцес або хронічне запалення епітеліальних куприкових ходів, що розташовуються в підшкірно-жировій клітковині міжсідничної складки в проекції крижово-куприкової ділянки, які анатомічно не зв'язані з останньою, і може мати ознаки хронічного запалення та рецидивуючого перебігу. Підтвердження цьому є факт, що зазвичай ПХ маніфестує появою в ділянці міжсідничної складки вторинного норицевого отвору у вигляді абсцесу. Епітеліальний куприковий хід (ЕКХ) являє собою вузький канал завдяки до $2-5$ см, що вистелений епітелієм, містить волосяні цибулини, сальні залози і який сліпо закінчується в м'яких тканинах над поверхнею куприка [2]. На шкірі ЕКХ відкривається одним-двома або більше (рідше) точковими воронкоподібними отворами на шкірі дна міжсідничної складки, які частіше розташовані один від одного на відстані 0,3 - 1,0 см. В первинних отворах часто можна бачити жмутки волосся [3]. Вперше EKX як самостійне захворювання описав A. Anderson (1847) у листі до редакції “Бостонского медицинского хирургического журнала” під назвою "Hair extracted from an ulcer" ("Волосся витягнуте із виразки") [4].

Частина аторів виникнення ПХ пов'язують із уродженою особливістю організму, наявністю кістоподібного підшкірного утворення в ділянці куприка, яке утворилось внаслідок інвагінації ектодерми на дні міжсідничної складки, пов'язаної із зворотною редукцією куприкових хребців або із потраплянням волосся підшкірно в результаті помпового механізму дії глибокої міжсідничної складки під час фізичних навантажень, фолікулярно-ретенційний генез [5, 6, 7]. Перевагу першому механізму зазвичай віддають хірурги та колопроктологи із країн пострадянського про- 
стору, другій же - європейські та американські автори. Однак обидва погляди на патогенез розвитку ПХ обов'язково містять в собі важливість ланки наявності волосяних фолікулів та/або вільного волосся у порожнині кісти. Важливим компонентом патогенезу ПХ автори вважають наявність первинних норицевих ходів, які виступають у ролі “вхідних воріт” для підшкірного “проникнення” волосся.

Однак дані уявлення зумовлюють ряд запитань: якщо при ПХ у підшкірній клітковині дна міжсідничної складки розташована ділянка шкіри з усіма її придатками (волосяними цибулинами 3 волоссям, потові та сальні залози), тоді чому не відбувається постійне інфікування та нагноєння цієї ділянки? I чому досить часто після первинного розкриття та тренування абсцесу виникає "самовільне” одужання пацієнта? Схоже питання викликає й теорія набутого генезу: якщо у людини під час рухів відбувається постійне “занурення” волосся у порожнину (що утворилася після самовільного розкриття абсцесу волосяного фолікула ділянки міжсідничної складки), тоді яким чином іноді відбувається “одужання” після хірургічного розкриття та дренування абсцесу? Адже волосся не має тенденції до біодеградації в організмі, а можливість зникнення ознак ПХ при первинному хірургічному втручанні у стадію гострого абсцесу покладена в основу багатьох іноземних та вітчизняних тематичних гайдлайнів.

Низка питань змушує до пошуку додаткових причин виникнення, підтримки хронічного запалення та рецидивного перебігу ПХ. Так, G. E. Karydakis у 1992 році опублікував дослідження на основі обстеження й лікування 6000 пацієнтів, в якому він стверджує, що обстрижене волосся, потрапляючи у іншу, “нормальну”, тканину викликає реакцію за типом стороннього тіла. Автор розробив формулу патогенезу ПХ, що має 3 основні змінні чинники: обстрижене волосся (Н), на яке впливають певні сили (F), що $є$ результатом дії таких вторинних факторів, як глибина, ширина та тертя в ділянці міжсідничної складки, і які безпосередньо викликають процес “проникнення” волосся в норицеві ходи. Третім фактором є локальна травматизація (V) шкіри та м'яких тканин:

$$
\Pi \mathrm{X}=\text { Hair }(\mathrm{H}) \times \text { Force }(\mathrm{F}) \times \text { Vulnerability }(\mathrm{V})[8]
$$

Однак дана формула не враховує низку уроджених та набутих особливостей організму, які мають значний вплив на частоту розвитку ПХ. До групи модифікуючих факторів можна віднести надлишкову масу; характер фізичної актив- ності та стилю життя; травматичні пошкодження куприка (падіння, удари); високий ступінь тертя та тиску на куприк (тривале сидіння у вимушеній позі). До немодифікуючих факторів належать: конституційний тип тілобудови та обтяжена спадковість; інтенсивність роботи потових та сальних залоз; порушення ембріонального розвитку у вигляді spina bifida occulta (аномалія розвитку задньої поверхні крижової кістки); форма, розмір та кількість волосся на тілі (особливо в ділянці міжсідничної складки); розміри пор шкіри над куприком; глибина та форма міжсідничної складки; схильність до закупорення волосяних фолікулів (гіпертрофовані сальні залози, вугрі). Потові та сальні залози, як і волосся, $є$ похідними шкіри, тому їх запалення в ділянці міжсідничної складки також необхідно розцінювати у якості анатомічних чинників ПХ.

Враховуючи сукупний вплив модифікуючих та немодифікуючих факторів у розвитку патологічного процесу, на сьогодні набула широкого розповсюдження теорія ПХ, яка базується на синдромі фолікулярної оклюзії. Розтягнуті пори в ділянці міжсідничної складки періодично закупорюються лусочками епітелію та секретом сальних залоз. В аналогічній ситуації на інших частинах тіла (тулуб, лице, кінцівки) такий процес призводить до формування акне, але міжсіднична складка (натальна розколина) - особлива анатомічна ділянка, при достатній глибині якої виникають умови для росту анаеробних бактерій, які призводять до розвитку та підтримки хронічного запального процесу, що змінює оточуючі тканини. Що ж стосується потових залоз, то у пацієнтів із надмірною масою тіла, малорухомим способом життя та підвищеною пітливістю тіла вони можуть сприяти підтримці хронічного запалення та рецидивну абсцесів у міжсідничній складці. Це виникає внаслідок утруднення та затримки виведення поту із просвіту останніх, що викликає їх перерозтягнення і появу асептичного запалення їх стінок. Згодом через проблематичність дотримання необхідної гігієни міжсідничної складки виникає септичний запальний процес, що призводить до утворення абсцесу. Крім того, надмірна локальна пітливість сприяє локальному подразненню шкіри, спричинюючи зменшенню ії захисної функції від проникнення патогенних та умовно-патогенних мікроорганізмів у товщу дерми; погіршенню умов дотримання гігієни крижово-куприкової та аноректальної ділянок; додатково утруднювати доступ кисню до дна міжсідничної складки, стимулюючи розвиток анаеробних мікроорганізмів в ділянці останньої. 
Таким чином, на сьогодні патогенез ПХ у дітей далекий від свого остаточного розуміння, в наслідок чого існують певні розбіжності на методологію іiї лікування [9]. Отже, низка зазначених та невирішених питань потребують подальшого вивчення та пошуку відповідей.

Мета роботи: визначити можливі анатомічні чинники патогенезу пілонідальної хвороби в дітей.

Матеріали і методи. У дослідження включено 37 дітей 3 діагнозом “пілонідальна хвороба”, які перебували на стаціонарному лікуванні в клініці дитячої хірургії Вінницького національного медичного університету імені М. І. Пирогова з 2010 по 2017 р. Середній вік пацієнтів складав $(16,4 \pm 0,4)$ р.; хлопчиків було 26, дівчаток - 11. 3 метою порівняння морфологічної будови ЕKX у дорослих проводили вивчення 17 зразків видалених тканин за архівами Вінницького обласного патологоанатомічного бюро. Інтраопераційно вилучені зразки тканин для дослідження обробляли за стандартною гістологічною методикою: фіксували у розчині 10 \% нейтрального формаліну протягом 24 год, зневоднювали у спиртах зростаючої концентрації (50 \%, 60 \%, 70 \%, 80 \%, 90 \% та 96 \%), просвітлювали двічі в ксилолі протягом 30 хв, витримували 2 год при температурі $37^{\circ} \mathrm{C}$ в суміші ксилолу та парафіну (1:1) та двічі - у парафіні протягом 30 хв при температурі $56{ }^{\circ} \mathrm{C}$, після чого заливали в чистий парафін. Зрізи завтовшки 5 мкм виконували на санному мікротомі, депарафінували в ксилолі, промивали 96 \% спиртом. Препарати забарвлювали гематоксиліном та еозином. Мікроскопію та картування гістологічних препаратів проводили за допомогою світлового мікроскопа OLIMPUS BX 41 при збільшенні в 100 та 200 раз, за допомогою програми “Quick PHOTO MICRO 2.3”.

Результати досліджень та їх обговорення. При гістологічному обстеженні навколо EKX у дітей в 15 (41,66 \%) спостереженнях на тлі незначного хронічного неспецифічного запалення визначалась незріла мезенхімоподібна тканина, серед якої в великій кількості виявлялись додатки шкіри (потові залози апокринового типу, деформовані волосяні фолікули з великою кількістю волосяних стрижнів), які глибоко розташовувались в оформленій фіброзній тканині та не були пов'язані зі шкірою в жодному випадку (рис. 1).

Мезенхімальна тканина являє собою ембріональний зачаток сполучної тканини, яка з'являється досить рано, одразу після формування листків зародка, заповнюючи проміжки між ними.

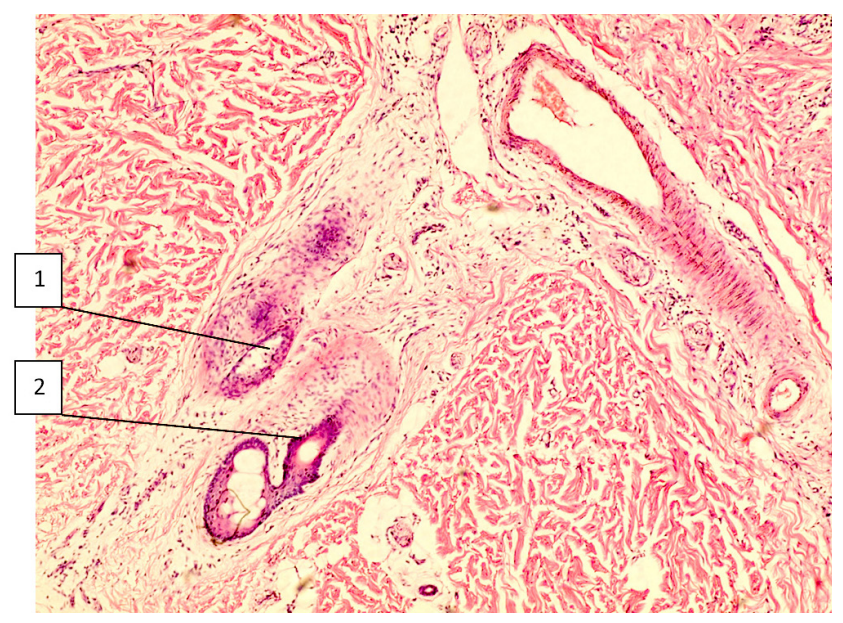

Рис. 1. Хибно розвинуті додатки шкіри в ділянці епітеліально-куприкових ходів: 1 - деформовані волосяні фолікули з великою кількістю волосяних стрижнів; 2 - потові залози апокринового типу, що розташовані серед набряклої незрілої мезенхімоподібної тканини з незначним хронічним неспецифічним запаленням, які розташовані глибоко в оформленій фіброзній тканині та не пов'язані зі шкірою. Забарвлення гематоксилін та еозин. $\times 100$.

Мезенхіма виникає переважно із мезодерми, хоча частина ï формується за рахунок клітин, які мають ектодермальне походження. Клітини мезенхіми поліпотентні та гетерогенні, що проявляється в різному походженні її клітин, які, у свою чергу, $€$ джерелами утворення багатьох видів сполучної тканини. Мезенхіма у зародка починає функціонувати як трофічна тканина, оскільки через неї відбувається обмін речовин. Пізніше внаслідок утворення в мезенхімі кровоносних судин, її трофічна функція вдосконалюється за рахунок того, що поживні речовини пересуваються тілом зародка по кровоносному руслі. Мезенхіма існує тільки в ембріональному періоді розвитку людини, повністю витрачаючись на утворення тканин зародка. Після народження в організмі людини зберігаються лише малодиференційовані клітини в складі пухкої волокнистої сполучної тканини (клітини адвентиції), які можуть дивергентно диференціюватись у різних напрямках, але в межах певної тканинної системи.

Враховуючи сутність природи мезенхімальної тканини, ії̈ вікову та функціональну потенцію, уявлення про “мезенхіму дорослого” неспроможне, оскільки в складі диференційованого організму незмінені клітини зародка в нормі не зберігаються [10].

При вивченні будови стінки куприкової кісти у дітей в 21 (58,33 \%) випадку виявлено, що просвіт останньої був вистелений багатошаровим плоским незроговіючим епітелієм (рис. 2). 


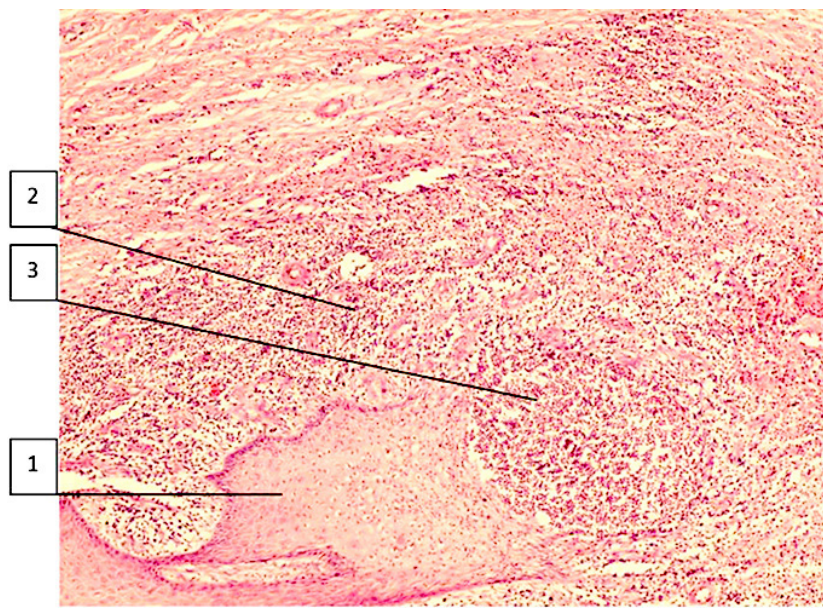

Рис. 2. Гнійно-продуктивне неспецифічне запалення в тканинах навколо куприкової кісти у дитини, вистеленої багатошаровим плоским незроговіючим епітелієм: 1 - багатошаровий плоский незроговіючий епітелій; 2 - порожнина куприкової кісти; 3 - молода грануляційна тканина $з$ вираженим лейкоцитарним валом із великою кількістю дрібних новоутворених судин. Забарвлення гематоксилін та еозин. × 100 .

У 12 (75,0 \%) препаратах епітеліальної куприкової кісти у дорослих на тлі ознак неспецифічного запалення та крововиливів в її стінку спостерігалась повна відсутність епітеліальної вистилки.

Даний факт, на наш погляд, слід розцінювати, і в тому числі, як закономірний наслідок значно тривалого рецидивного перебігу ПХ, з частими періодами ускладнень (запалення та абсцедування), внаслідок яких створюються відповідні умови для повної десквамації епітеліальної висилки ЕKX, із заміщенням його грануляційною тканиною.

Тотальна відсутність епітелію в просвіті ЕKX сприяє швидкому розвитку хронізації запального процесу, внаслідок якого виникає гіаліноз судинних стінок безпосередньо в стінці кісти внаслідок місцевих порушень сполучної тканини. Значне звуження просвіту гіалінізованої судини спричинює баротравму, яка в нормі попереджається скороченням артеріоли, а втративши еластичність та здатність до скорочення гідродинамічний удар призводить до плазматичного просякнення дистальних ділянок тканин, які ними кровопостачаються, із втратою їх функцій та підвищенням гідрофільності. В більшості випадків гіаліноз незворотний, а при розповсюдженні його на значній площі виникають значні функціональні порушення через підвищення проникнення стінок дрібних артерій та артеріол, звуження їх посвіту на тлі підвищеного артеріального тиску в них, що, у свою чергу, служить морфологічним субстратом для інфікування та розвитку запального процесу в оточуючих тканинах $[11,12]$.
Під час дослідження епітеліальних куприкових кіст у дорослих у 15 (93,75 \%) випадках структури, які оточували ЕKX, складались із грубоволокнистої сполучної тканини 3 вираженою лімфогістіоцитарною інфільтрацією. Просвіти ЕKX містили зроговілі маси, злущені клітини поверхневого шару, уламки волосся та цілі волосяні стрижні, а стінка ходів вистелена грануляційною тканиною. Покривний багатошаровий плоский епітелій навколо норицевих ходів був різко потовщений, складаючись із 20 - 22 шарів, часто з ознаками ангіоматозу (рис. 3).

Схожі морфологічні знахідки у дітей при ПХ були виявлені лише у 11 (30,55 \%) пацієнтів віком 17 - 18 років при рецидивному перебігу захворювання. Однак, на відміну від дорослих, не спостерігались волосяні стрижні з ознаками повного лізису, визначались лише ознаки початкової деструкції волосяних стрижнів, які були пов'язані із волосяними фолікулами та неатрофованими волосяними цибулинами, що чітко не свідчило на користь їх екзогенного трансдермального проникнення.

У міжсідничній складці шкіра досить щільно з'єднана із прилеглими фасцією та окістям. При зміні положення тіла (вертикалізації), тривалій ходьбі та невдало обраній позі, при сидінні відбувається надмірне зміщення шкіри в крижовокуприковій ділянці та розтягнення iï пор. За цих умов пори стають ширшими та глибшими. Крім того, витягнуті та широкі пори сприяють накопиченню в них змертвілих клітин шкіри, сального секрету, поту, а іноді і фрагментів волосся. Це “сміття”, заповнюючи пору, ще більше ії розтягує,

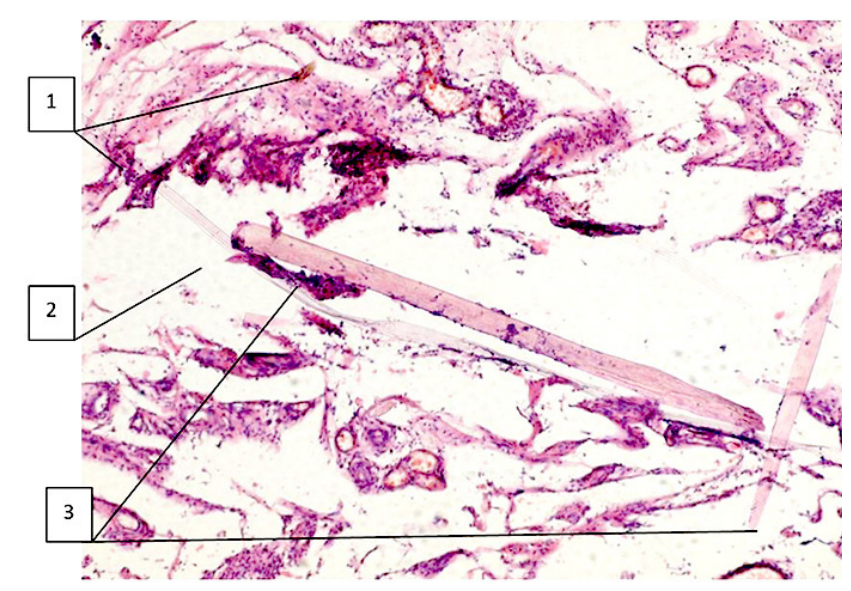

Рис. 3. Наявність уламків товстих волосяних стрижнів у стінці та в порожнині епітеліально-куприкової кісти 3 хронічним запаленням у дорослого: 1 уламки волосяних стрижнів у стінці кісти; 2 - порожнина в стінці кісти на місці стрижня, який випав; 3 уламки волосяних стрижнів у порожнині кісти. Забарвлення гематоксилін та еозин. $\times 100$. 
а при виникненні запалення сприяє її самостійному розкриттю. Таким чином формується пілонідальна порожнина, в якій створюються сприятливі умови для розвитку патогенних мікробів. Саме тому при ПХ не завжди у порожнині абсцесу/кісти виявляється вільне волосся та можуть не визначатись первинні норицеві ходи.

Яскравою демонстрацією даного механізму утворення пілонідального абсцесу є такий клінічний випадок. Хворий С., 17 р., МКСХ № 13438 госпіталізований до хірургічного стаціонару із скаргами на біль та наявність пухлиноподібного утворення розмірами 3,0×4,5 см в крижово-куприковій ділянці. Утворення при пальпації еластичної консистенції, болюче, шкіра над ним гіперемійована, в центрі визначається флуктуація. 3 анамнезу, пацієнт акцентує увагу на факті підвищеного виділення поту в проекції міжсідничної складки протягом останнього місяця. Діагноз при госпіталізації: пілонідальна кіста. Проведено операційне втручання - розкриття та дренування кісти. Інтраопераційно із порожнини кісти отримано до 2,0 мл гною. Проведено біопсію стінки кісти.

Гістологічне заключення по біоптату № 5164568: стінка кісти утворена оформленою фіброзною тканиною, в якій визначаються множинні сальні та гіпертрофовані потові залози, дифузна поліморфноклітинна запальна інфільтрація з переважанням сегментоядерних нейтрофілів, еозинофілів, вогнища некрозу та вогнищеві крововиливи. Вистилка кісти не простежується (рис. 4).

Певним підтвердженням важливості надмірної продукції секрету потових залоз є той факт, що ПХ пов'язана з деякими спорідненими за походженням захворюваннями, а саме: acne congobata (шароподібні або нагромаджені вугрі) - один із найтяжчих проявів вугрової хвороби, яка трапляється у чоловіків на фоні густої себореї та проявляється множинними вузловато-кістозними елементами на шкірі кінцівок, живота, спини; dissecting cellulitis (розсікаючий целюліт або абсцедуючий перифолікуліт голови) - хронічні перифолікулярні пустули, вузлики і абсцеси, які виникають переважно у чоловіків негроїдної раси на другому-

\section{СПИСОК ЛІТЕРАТУРИ}

1. Цема Є. В. Клініко-морфологічні аспекти етіопатогенезу пілонідальних кіст крижово-куприкової ділянки / Є. В. Цема, Ю. В. Діброва // Патологія. - 2013. - № 3(29). - С. 61 - 65. 2. Тресоруков И. В. Способ одномоментного хирургического лечения гнойно-свищевых форм эпителиальнокопчикового хода / И. В. Тресоруков, К. А. Корейба, С. Л. Демьянов // Вестник экспериментальной и клинической хирургии. - 2011. - T. IV, № 1. - С. 170 - 172.

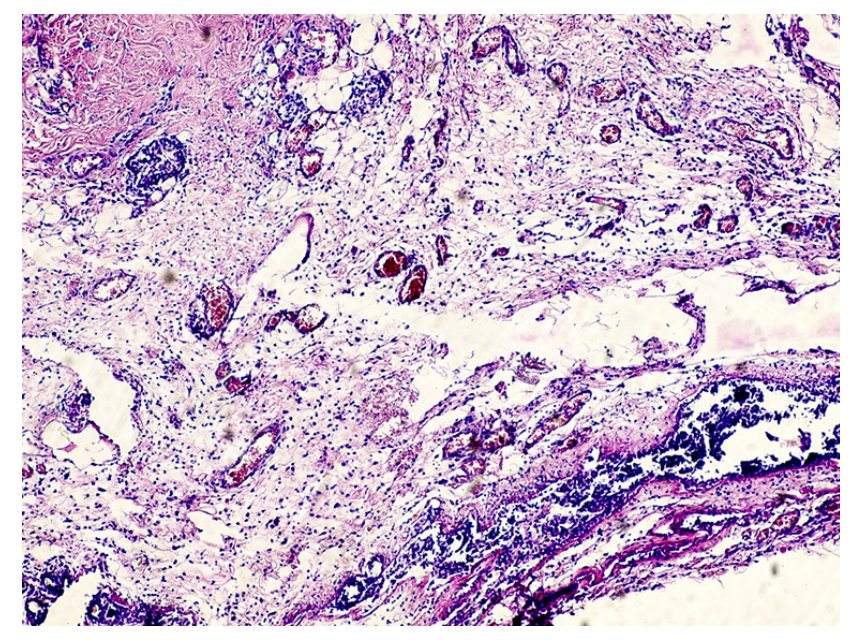

Рис. 4. Хворий С., 17 р., МКСХ № 13438. Мікрофотографія біоптату стінки пілонідальної кісти: множинні гіпертрофовані потові залози, дифузна поліморфноклітинна запальна інфільтрація з вогнищами некрозу та вогнищевими крововиливами. Забарвлення гематоксилін та еозин. $\times 100$.

третьому десятку життя; hidradenitis supperativa - хронічне захворювання шкіри, для якого характерна поява запального процесу в потових залозах, частіше в аксилярних ділянках, під молочними залозами, пахвинних ділянках. У таких пацієнтів часто фіксують виникнення ПХ.

Висновки. Пілонідальна хвороба - це поліетіологічне захворювання, однією із причин розвитку якої є підвищена локальна пітливість тіла, що зумовлює ряд додаткових провокуючих факторів утворення гострого абсцесу міжсідничної ділянки, підтримання хронічного запалення та рецидивного перебігу захворювання.

Перспективи подальших досліджень. Дана проблема потребує подальшого вивчення патогенетичних чинників у дітей для розширення уявлень щодо розуміння причин ії̈ виникнення, що дасть змогу прогнозувати і попереджувати виникнення ПХ та уникати можливої появи рецидиву хвороби.
3. Шелыгин Ю.А. Справочник по колопроктологии / Ю. А. Шелыгин, Л. А. Благодарный. - М. : Литтера, 2012. C. $135-142$.

4. Anderson A. Hair extracted from an ulcer / A. Anderson // Boston Med. Surg. J. - 1847. - Vol. 36, No. 4. - P. 74-76.

5. Раменский С. Б. Эпителиальные кисты и ходы крестцовокопчиковой области / С. Б. Раменский // Вестник хиркургии. - 1960. - № 2. - С. 101 - 104. 
6. Дульцев Ю. В. Эпителиальный копчиковый ход / Ю. В. Дульцев, В. Л. Ривкин. - М., 1988. - 128 с.

7. Bascom J. Pilonidal disease: origin from follicles of hairs and results of follicle removal as treatment // Surgery. - 1980. No. 87 (5). - P. 567-572.

8. Karydakis G. E. Easy and successful treatment of pilonidal sinus after explanation of its causative process / G. E. Karydakis // Aust. N. Z. J. Surg. - 1992. - Vol.62, No. 5. - P. 385-389.

9. Новый способ пластики межъягодичной складки в радикальном лечении эпителиального копчикового хода / Е. В. Можанов, О. Ю. Карпухин, А. Ф. Шакуров, Р. Р. За- рипов // Практическая медицина. - 2017. - № 6. - С. 34 - 36. 10. Волкова О. В. Эмбриогенез и возрастная гистология внутренних органов человека / О. В. Волкова, М. И. Пекарский. - М. : “Медицина”, 1976. - 414 с.

11. Русак О. Б. Морфологічні особливості епітеліальних куприкових ходів у гострій та хронічній фазах / О. Б. Русак // Шпитальна хірургія. - 2009. - № 4. - С. 58 - 61.

12. Цема $€$. В. Результати екстреного радикального хірургічного лікування пілонідальної кісти, ускладненої гострим абсцесом / Є. В. Цема, А. М. Кулик // Український журнал хірургіï. - 2013. - № 4. - С. 73 - 77.

\section{REFERENCES}

1. Tsema, Ie.V., \& Dibrova, Yu.V. (2013). Klinikomorfolohichni aspekty etiopatohenezu pilonidalnykh kist kryzhovo-kuprykovoi dilianky [Clinical and morphological aspects of etiopathogenesis of pylonodal cysts of sacrococcygeal area]. Patolohiia - Pathology, 3 (29), 61-65 [in Ukrainian].

2. Tresorukov, I.V., Koreyba, K.A., \& Demianov, S.L. (2011). Sposob odnomomentnogo khirurgicheskogo lecheniya gnoynosvishchevykh form epitelialno-kopchikovogo khoda [Method for simultaneous surgical treatment of purulent-fistulous epithelialcoccygeal stroke]. Vestnik eksperimentalnoy i klinicheskoy khirurgii - Journal of Experimental and Clinical Surgery, IV (1), 170-172 [in Russian].

3. Shelygin, Yu.A., \& Blagodarnyy, L.A. (2012). Spravochnik po koloproktologii [Coloproctology handbook]. Moscow: Littera [in Russian].

4. Anderson, A. (1847). Hair extracted from an ulcer. Boston Med. Surg. J., 36 (4), 74-76.

5. Ramenskiy, S.B. (1960). Epitelialnyye kisty i khody kresttsovo-kopchikovoy oblasti [Epithelial cysts and strokes of sacrococcygeal region]. Vestnik khirkurgii - Herald of Surgery, 2, 101-104 [in Russian].

6. Dultsev, Yu.V., \& Rivkin, V.L. (1988). Epitelialnyy kopchikovyy khod [Epithelial coccygeal stroke]. Moscow [in Russian].

7. Bascom, J. (1980). Pilonidal disease: origin from follicles of hairs and results of follicle removal as treatment. Surgery, 87 (5), 567-572. 8. Karydakis, G.E. (1992). Easy and successful treatment of pilonidal sinus after explanation of its causative process. Aust. N. Z. J. Surg., 62 (5), 385-389.

9. Mozhanov, E.V., Karpukhin, O.Yu., Shakurov, A.F., \& Zaripov, R.R. (2017). Novyy sposob plastiki mezhyagodichnoy skladki v radikalnom lechenii epitelialnogo kopchikovogo khoda [A new method of interglacial fold plastics in the radical treatment of the epithelial coccyx stroke]. Prakticheskaya meditsina Practical Medicine, 6, 34-36. [in Russian].

10. Volkova, O.V. (1976). Embriogenez i vozrastnaya gistologiya vnutrennikh organov cheloveka [Embryogenesis and age histology of human internal organs]. Meditsina - Medicine, 414 [in Russian]. 11. Rusak, O.B. (2009). Morfolohichni osoblyvosti epitelialnykh kuprykovykh khodiv u hostrii ta khronichnii fazakh [Morphological characteristic of epithelial coccygeal passages of courses in acute and chronic phases]. Shpytalna khirurhiia Hospital Surgery, 4, 58-61 [in Ukrainian].

12. Tsema, Ye.V., \& Kulyk, A.M. (2013). Rezultaty ekstrenoho radykalnoho khirurhichnoho likuvannia pilonidalnoi kisty, uskladnenoi hostrym abstsesom [Results of emergency radical surgical treatment of pilonidal cyst, complicated by acute abscess]. Ukrainskyi zhurnal khirurhii - Ukrainian Journal of Surgery, 4, 73-77 [in Ukrainian].

\section{PILONIDAL DESEASE IN CHILDREN. ARE ALL ISSUES OF PATHOGENESIS SOLVED?}

The aim of the work: to determinate the possible anatomical factors in the pathogenesis of pilonidal disease in children.

Materials and Methods. Analysis of the results of clinical and morphological examination of 37 children diagnosed with "pilonidal disease" treated from 2010 to 2017 on the basis of Vinnytsia Regional Children’s Clinical Hospital was carried out in the study. The gender distribution of patients was 26 boys and 11 girls. The average age of patients was (16.4 \pm 0.4$)$ years. To compare the morphological structure of the pilonidal cyst with adult patients, 17 samples of previously removed tissues were used, which were registered in the archive of the regional pathanatomical bureau.

Results and Discussion. In $75 \%$ drugs in adults, there was a lack of epithelial lining, which is the result of a long recurrence of pilonidal disease. It is contributes to the rapid chronization of the inflammatory process and the emergence of vascular walls hyalinosis in the cyst wall. Also, in almost $94 \%$ of cases in adults the walls of the pilonoid cyst consisted of coarse fibrous connective tissue with severe lymphohistiocytic infiltration, and in the lumen they were determined derive of the skin. Similar morphological signs were detected in 


\section{З ДОСВІДУ РОБОТИ}

only $30 \%$ of children, and in the cavity of the cyst, hair strains with signs of partial lysis that were associated with non-atrophied hair follicles were revealed. This clearly did not indicate the benefit of their exogenous transdermal penetration. In $41.66 \%$ of children, in the histological examination around the coccygeal course, immature mesenchymal tissue was determined. Due to the tight fixation of the skin in the intergluteal fold and surrounding tissues, the movement of skin and stretching of pores, in which the secrets of the skin and its derivatives accumulate, occur during movements. They even more stretch it and in case of inflammation contribute to its unauthorized disclosure. Therefore, pilonidal disease is a polyethiologic disease, one of the reasons for which is the increased local sweating of the body, causing a number of additional provocative factors of the formation of acute abscess in the intergluteal area, maintaining chronic inflammation and recurrent course of the disease.

Key words: pilonidal disease; children; pediatric surgery.

\section{В. С. КОНОПЛИЦКИЙ ${ }^{1}$, Р. В. ШАВЛЮК ${ }^{1}$, В. М. ШАВЛЮК ${ }^{2}$}

Винницкий национальный медицинский университет имени Н. И. Пирогова ${ }^{1}$ КП “Казатинская центральная районная больница"

\section{ПИЛОНИДАЛЬНАЯ БОЛЕЗНЬ У ДЕТЕЙ. ВСЕ ЛИ ВОПРОСЫ ПАТОГЕНЕЗА РЕШЕНЫ?}

Цель работы: определить анатомические факторы патогенеза пилонидальной болезни у детей.

Материалы и методы. Проведено анализ результатов клинико-морфологических обследований 37 детей с диагнозом “пилонидальная болезнь”, пролеченных с 2010 по 2017 год на базе Винницкой областной детской клинической больницы. Средний возраст пациентов составлял $(6,4 \pm 0,4)$ года; 26 мальчиков было и 11 девочек. Для сравнения морфологической структуры пилонидальной кисты со взрослыми пациентами использовали 17 образцов удаленных раньше тканей, которые находились на учете в архиве областного патанатомического бюро.

Результаты исследований и их обсуждение. В 75 \% препаратов у взрослых наблюдалось отсутствие эпителиальной выстелки, что есть результатом длительного рецидивирующего течения пилонидальной болезни. Последнее сопутствует быстрой хронизации воспалительного процесса и возникновению гиалиноза сосудистых стенок в стенке кисты. Также почти в 94 \% случаев у взрослых стенка пилонидальной кисты состояла из грубоволокнистой соединительной ткани из выраженной лимфогистиоцитарной инфильтрацией, а в просвете их определялись дериваты кожи. Похожие морфологические признаки были определенны только у 30 \% детей, а в полости кисты были найдены волосяные стержни с признаками частичного лизиса, что были связаны с неатрофированными волосяными луковицами, что четко не свидетельствует на пользу их экзогенного трансдермального проникновения. В 41,66 \% детей при гистологическом обследовании вокруг копчикового хода определялась незрелая мезенхимовидная ткань. За счет плотной фиксации кожи межягодичной складки из окружающими тканями при движении возникает смещение ее и растяжение пор, в которых накапливается секрет кожи и ее дериваты. Последние же еще больше ее растягивают и при возникновении воспаления сопутствуют ее самостоятельному раскрытию. Поэтому пилонидальная болезнь - полиэтиологическое заболевание, одной из причин возникновения которой является повышенная локальная потливость тела, что вызывает ряд дополнительных провокационных факторов развития острого абсцесса межягодичной области, поддержания хронического воспалительного процесса и рецидивирующего течения заболевания.

Ключевые слова: пилонидальная болезнь; дети; детская хирургия. 